\title{
Eksplorasi Pemberdayaan Masyarakat Dalam Pilar Lingkungan Melalui Program Pemberdayaan Keluarga
}

\author{
Arif Abdul Haqq ${ }^{1}$, Zakiyyah ${ }^{2}$ \\ IAIN Syekh Nurjati Cirebon ${ }^{1}$, Universitas Muhammadiyah Cirebon ${ }^{2}$ \\ 1e-mail:mr.haqq@gmail.com \\ e-mail: zakiyyah@umc.ac.id
}

\begin{abstract}
ABSTRAK
Seperti permasalahan lingkungan pada umumnya, Desa Kubangwungu juga mempunyai masalah dalam bidang lingkungan, yaitu sebagian masyarakat yang masih memiliki kebiasaan dalam membuang sampah sembarangan. Sehingga sampah berserakan, menyumbat saluran air dan menumpuk pada sungai-sungai. Hal ini menyebabkan sungai meluap dan banjir. Penlitian ini bertujuan untuk menggambarkan secara menyeluruh tentang implementasi pemberdayaan masyarakat dalam pilar lingkungan melalui program pemberdayaan keluarga (POSDAYA). Jenis Penelitian adalah penelitian kualitatif deskriptif dengan pendekatan program kemitraan. Hasil penelitian menunjukkan bahwa pelaksanaan kegiatan pemberdayaan masyarakat berbasis keluarga dilaksanakan sejak bulan Juli 2019 hingga Agustus 2019 di Desa Kubangwungu Kecamatan Ketanggungan Kabupaten Brebes Provinsi Jawa Tengah. Dengan mengoptimalkan peran keluarga sebagai sentra kegiatan menjadi faktor utama terselenggaranya kegiatan posdaya berbasis keluarga. Kegiatan tersebut diantaranya, pembuatan kebun bergizi, pemanfaatan limbah rumah tangga, pembuatan biopori, pembuatan bank sampah, manajemen dan mekanisme bank sampah. Kegiatan-kegiatan tersebut ternyata dapat meningkatkan kepedulian masyarakat terhadap lingkungan sebagai implikasi dari pemberdayaan masyarakat di bidang lingkungan.
\end{abstract}

Kata kunci: Limbah rumah tangga, Pengelolaan lingkungan, Keluarga, Kepedulian

\begin{abstract}
As with environmental problems in general, Kubangwungu Village also has issues in the ecological field, namely some people who still have the habit of littering. So that rubbish littered clogged waterways and piled up in rivers. This causes the river to overflow and flood. This research aims to give a comprehensive picture of the implementation of community empowerment in the pillars of the environment through the family empowerment program (POSDAYA). This type of research is descriptive research with a partnership program. The results showed that the implementation of family-based community empowerment activities was carried out from July 2019 to August 2019 in Kubangwungu Village, Ketanggungan District, Brebes Regency, Central Java Province. Optimizing the role of the family as an activity center is a significant factor in the implementation of family-based posdaya activities. These activities include making nutritious gardens, utilizing household waste, making biopori, making waste banks, management, and mechanisms of waste banks. These activities turned out to be able to increase public awareness of the environment as an implication of community empowerment in the environmental field.
\end{abstract}

Keywords: Household waste, Environmental management, Family, Care 


\section{PENDAHULUAN}

Keluarga sebagai bagian tak terpisahkan dari masyarakat Indonesia yang memiliki posisi serta kedudukan yang strategis bagi sebuah proses pertumbuhan, perkembangan dan kelangsungan hidup masyarakat dan bangsanya. Kedudukan keluarga dalam kehidupan masyarakat berada pada ujung tombak ditingkat dasar dalam struktur kebangsaan. Hal tersebut diperkuat oleh pendapat Naufal \& Kusumastuti (2016) yang menyatakan bahwa keluarga sebagai ujung tombak untuk memperbaiki pendidikan, kesehatan dan ekonomi masyarakat dengan pilar keswadayaan dan kemandirian sebagai semangat kerjanya termasuk dalam edukasi masyarakat mengenai problematika lingkungan.

Persoalan lingkungan dewasa ini menjadi sorotan masalah yang serius. Masyarakat yang berperan sebagai pelaku konsumen sudah pasti menghasilkan limbah rumah tangganya sendiri. Seperti yang dijelaskan oleh Sunarsi (2014) bahwa masyarakat melalui kegiatan konsumsinya menghasilkan limbah padat, limbah cair, atau dapat juga berupa limbah gas. Sudah merupakan tradisional semakin banyak masyarakat yang membuang limbah rumah tangganya langsung ke lingkungan. Hal inilah yang menjadi penyebab utama terjadinya pencemaran bahkan kerusakan terhadap lingkungan. Misalnya terjadinya banjir dikarenakan saluran air dan sungai yang tersumbat karena masyarakat membuang limbah padatnya ke saluran air atau sungai tersebut. Akibat yang dapat ditimbulkan yaitu terjadinya kerusakan lingkungan pada tempat-tempat pembuangan limbah rumah tangga seperti sungai.

Problematika lingkungan yang ini memerlukan solusi yang serius dari masyarakat. Keseriusan masyarakat merupakan faktor utama keberhasilan dalam pengelolaan limbah rumah tangga. Seperti halnya tercantum dalam PP RI No. 81 Tahun 2012 tentang pengelolaan limbah rumah tangga dan sampah sejenis sampah rumah tangga terutama pada poin $\mathrm{f}$ yang menyebutkkan multi peran yang dipegang masyarakat seperti pembuat keputusan, penyelenggaraan, dan pengawasan dalam kegiatan pengelolaan sampah rumah tangga (Nurul Inayah \& Ribut Suprapto, 2017). Untuk itu peningkatan kepedulian masyarakat terhadap lingkungan melalui gerakan literasi maupun program kemitraan merupakan hal utama dalam pengelolaan linbah rumah tangga.

Pencemaran lingkungan merupakan penurunan kualitas lingkungan sampai pada tingkat tertentu yang menyebabkan lingkungan mengalami disfungsi sesuai perannya (Wahyudin, 2017). Pencemaran lingkungan merupakan awal mula terjadi kerusakan lingkungan. Kerusakan pada lingkungan mengacu pada dua jenis bencana yang berakibat pada rusaknya sokongan dari lingkungan itu sendiri dan kerusakan yang berasal dari perilaku masyarakatnya. Bagi masyarakat, kerusakan yang berasal dari lingkungan ini sulit dihindari karena tidak dapat diperkirakan kapan terjadinya. Dapat berdampak dalam waktu yang singkat, atau bahkan berdampak dalam waktu 
yang lama. Kerusakan lingkungan yang berasal dari perilaku masyarakat, terutama beralasan demi meningkatkan kualitas dan kenyamanan hidup, seperti kerusakan sokongan sebagai akibat dari kegiatan-kegiatan indrustri, penggunaan bahan bakar fosil dan limbah rumah tangga yang dibuang di sungai-sungai.

Edukasi masyarakat mengenai pengelolaan sumberdaya lingkungan dan problematikanya sangat perlu. Edukasi ini meliputi literasi lingkungan dan keterampilan dalam mengelola limbah rumah tangga yang dapat menggiring perilaku kepedulian terhadap lingkungan dan tindakan peduli lingkungan ke arah yang positif. Gagasan ini sejalan dengan Zakiyyah, Zuhud, \& Sumardjo (2016) yang menyatakan bahwa sikap dan perilaku masyarakat, serta aksinya terhadap lingkungan merupakan hasil stimulus dari pengetahuan dan keterampilan dalam mengelola lingkungan itu sendiri. Kegiatan literasi lingkungan dan keterampilan dalam mengelola limbah rumah tangga dieksplorasi melalui pos pemberdayaan keluarga (POSDAYA). POSDAYA merupakan sebuah wadah atau lembaga yang berfungsi sebagai forum diskusi, silaturahmi, advokasi, komunikasi, edukasi, dan wadah kegiatan penguatan fungsi-fungsi keluarga secara terpadu yang dilaksanakan dari, oleh, dan untuk keluarga dan masyarakat (Zakiyyah \& Haqq, 2018).

Kepedulian masyarakat Desa Kubangwungu Kecamatan Ketanggungan Kabupaten Brebes terhadap lingkungan masih dikategorikan pada kategori rendah. Hal ini dibuktikan dengan masih banyak warga masyarakat yang membuang limbah rumah tangga baik limbah padat maupun cair ke sungai sehingga sungai menjadi kotor dan tercemar. Karena fenomena tersebutlah, maka diadakanlah penyuluhan limbah rumah tangga dan pemanfaatannya. Selain workshop, diberikan pula pemaparan informasi terkait dampak negative dari pengelolaan sampah rumah tangga yang tidak dikelola dengan benar.

Desfandi (2015) mengungkapkan bahwa masyarakat internasional saat ini telah menyepakati pentingnya menjaga bumi dari pencemaran dan kerusakan dengan memahami interkasi antara alam dengan masyarakat guna kelangsungan hidup yang bersifat kontinuitas. Dengan memberikan informasi mengenai pengelolaan sampah rumah tangga yang benar, masyarakat menambah kemampuan literasi lingkungan. Selain itu, masyarakat mampu mengembangkan keterampilannya dalam memanfaatkan minyak jelantah menjadi sabun melalui kegiatan workshop tersebut. Selain itu, masyarakat juga diberdayakan melalui program kemitraan berupa kebun bergizi, pembuatan kerajinan tangan dari limbah padat sendok makan plastik dan kardus, pembuatan perangkap tikus dan nyamuk, dan pemuatan biopori guna mencegah banjir. Oleh karenanya dalam penelitian ini dibahas tentang eksplorasi pemberdayaan masyarakat dalam pilar lingkungan melalui program pemberdayaan keluarga melalui literasi lingkungan dan 
keterampilan dalam mengelola limbah rumah tangga yang dapat menggiring perilaku kepedulian terhadap lingkungan dan tindakan peduli lingkungan ke arah yang positif.

\section{BAHAN DAN METODE}

Penelitian ini dilaksanakan sejak Bulan Juli - Agustus 2019. Wilayah penelitian berada di Desa Kubangwungu Kecamatan Ketanggungan, Kabupaten Brebes. Jenis penelitian ini adalah penelitian kualitatif deskriptif. Pendekatan yang digunakan dalam penelitian ini adalah Pos Pemberdayaan Keloarga dengan pendekatan Participatory Action Research (PAR). Pendekatan ini memiliki keutamaan yaitu suatu langkah-langkah suatu kelompok masyarakat atau sosial menyelesaikan masalah mereka dengan cara ilmiah dengan melakukan pengarahan, perbaikan, dan pengevaluasian keputusan atas langkah-langkah yang dilakukan oleh mereka sendiri (masyarakat) (Ratnadewi, 2019). Usaha untuk melakukan penelusuran, pemahaman, penjelasan gejala dan kaitan hubungan antara gejala yang diteliti dari komponen tertentu menjadi dasar digunakannya pendekatan tersebut. Model yang digunakan untuk melakukan analisis data adalah Model Analisis Interaktif Miles dan Huberman.

Menurut Sukmawati (2013) model tersebut dapat memiliki empat tahapan, yaitu: (1) Tahap pengumpulan data, pada tahap ini peneliti melakukan proses pengumpulan data dengan menggunakan teknik pengumpulan data yang telah ditentukan; (2) Tahap reduksi data, pada tahap ini, peneliti melakukan pemilihan, pemusatan perhatian pada penyederhanaan, pengabstrakan, dan transformasi data kasar yang muncul dari catatan-catatan tertulis dari lapangan; (3) Tahap penyajian data, tahap ini merupakan penyajian data dari informasi yang tersusun yang memberi kemungkinan adanya penarikan kesimpulan dan pengambilan tindakan; dan yang terakhir adalah (4) Tahap verifikasi/penarikan kesimpulan, pada tahap ini merupakan tahap akhir, yang berupa penarikan kesimpulan dari data yang telah ditampilkan. Adapun ilustrasinya ditampilkan pada Gambar 1 berikut: 


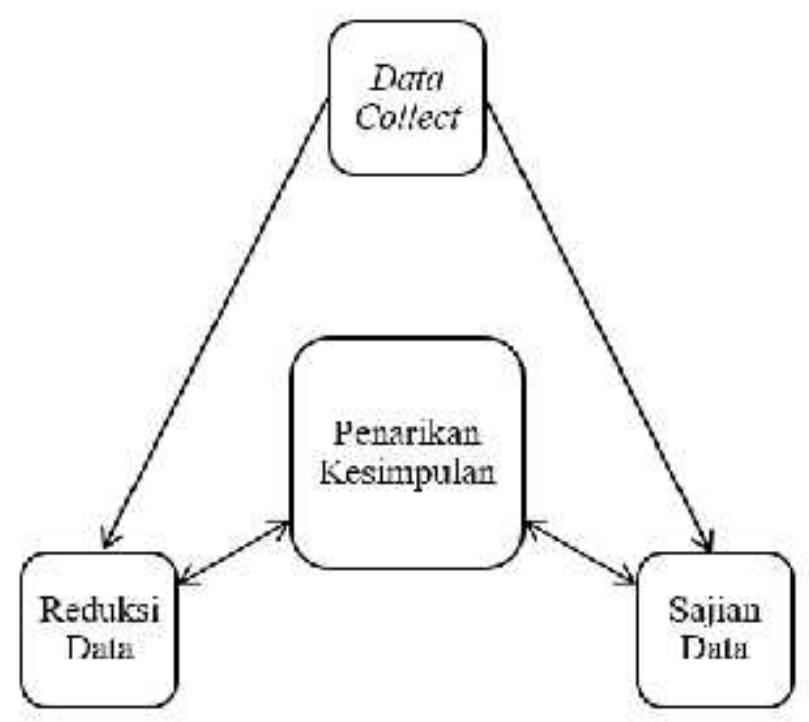

\section{Gambar 1. Model Analisis Interaktif dari Miles dan Huberman}

Sumber: Sukmawati, 2013

Teknik pengumpulan data menggunakan metode: (1) pengamatan, yang digunakan untuk mengamati hasil berupa kondisi fisik apa saja yang telah dilaksanakan/diwujudkan oleh kepala desa dalam rangka pembaharuan kepada masyarakat tentang pertanian berbasis teknologi dan pendukungnya. Kegiatan masyarakat dalam mempraktekkan pertanian berbasis teknologi. Kegiatan lainnya yang mendukung pelaksanaan pembaharuan pada masyarakat Desa Mlatiharjo; (2) wawancara, yang dugnakan untuk mewawancarai kepala desa sebagai agen perubahan utama, perangkat desa, dan penduduk Desa Sumurkondang, (3) dokumentasi, dokumen digunakan sebagai sumber sekunder, dalam hal ini berarti dokumen bias digunakan sebagai suatu cara untuk melakukan pengecekan silang (cross check) terhadap informasi yang telah diperoleh dari sumber lain, missal dari hasil wawancara; (4) triangulasi, yaitu tehnik yang menggabungkan beberapa teknik pengumpulan data dan sumber data yang telah ada. Uji objektivitas data penelitian ini dilakukan dengan menggunakan teknik: (1) triangulasi sumber, yaitu dengan melakukan pengecekan data tentang kondisi masyarakat dari sumber lisan (informan) seperti kepala desa, perangkat desa dan sumber pendukung lainnya dengan sumber tertulis; (2) review informan, yaitu dengan melakukan pengecekan hasil penelitian oleh para informan.

Data yang terkumpul merupakan data lapangan dan data pustaka. Adapun pengambilan dan sumber data dari kedua jenis data tersebut adalah sebagai berikut: Data lapangan yaitu melalui observasi langsung dengan masyarakat Desa Kubangwungu. Data pustaka dijadikan data suplemen dari data lapangan. Adapun responden yang diteliti adalah meliputi masyarakat Desa Kubangwungu yang ikut aktif dalam POSDAYA pada kegiatan literasi lingkungan dan keterampilan pengelolaan lingkungan. Responden masyarakat tersebut diambil sampel dengan 
menggunakan teknik pengambilan sampel non-probability sampling. Mayoritas responden adalah ibu-ibu rumah tangga yang berprofesi sebagai buruh tani dan buruh tali tambang.

\section{HASIL DAN PEMBAHASAN}

\section{Gambaran Umum Lokasi Penelitian}

Secara administratif Desa Kubangwungu Kecamatan Ketanggungan Kabupaten Brebes, Provinsi Jawa Tengah merupakan salah satu dari 21 (dua puluh satu) desa di Kecamatan Ketanggungan yang mempunyai jarak 28 km dari kota kabupaten. Desa Kubangwungu terdiri dari 3 (tiga) dusun 5 (lima) RW, dan 33 (tiga puluh tiga) RT dengan luas 556,6 Ha. Desa ini memiliki potensi perangkat yang terdiri dari seorang Kepala Desa (Kades), satu orang Sekretaris Desa (Sekdes), empat orang Kaur, tiga Kepala Dusun (Kadus), satu orang Pembantu Kadus, dan satu orang Pembantu Kaur Kersa. Batas wilayah Desa Kubangwangu dari sebelah utara adalah Desa dukuhturi - Desa Karangmalang; sebelah timur adalah Desa Luwunggede - Desa Karangbale - Desa Larangan; Sebelah selatan adalah Desa Kubangsari - Desa Baros; dan Sebelah barat adalah Desa Tanggungsari. Adapun orbitrasi wilayah, seperti: Jarak ke ibu kota kecamatan adalah $3 \mathrm{Km}$, Jarak ke ibu kota kabupaten $8 \mathrm{Km}$, lama tempuh ke ibu kota kecamatan 0,25 Jam, dan lama tempuh ke ibu kota kabupaten 1 Jam

Jumlah penduduk Desa Kubangwungu pada tahun 2019 adalah 8.124 jiwa yang terdiri dari 4.107 laki-laki dan 4.017 perempuan. Jumlah KK di Desa Windujaya pada tahun 2019 adalah sebanyak 3.457 KK dengan 1.314 KK diantaranya adalah Rumah Tangga Miskin (RTM). Berikut gambaran keadaan perekonomian di Desa kubangwungu tahun 2019:

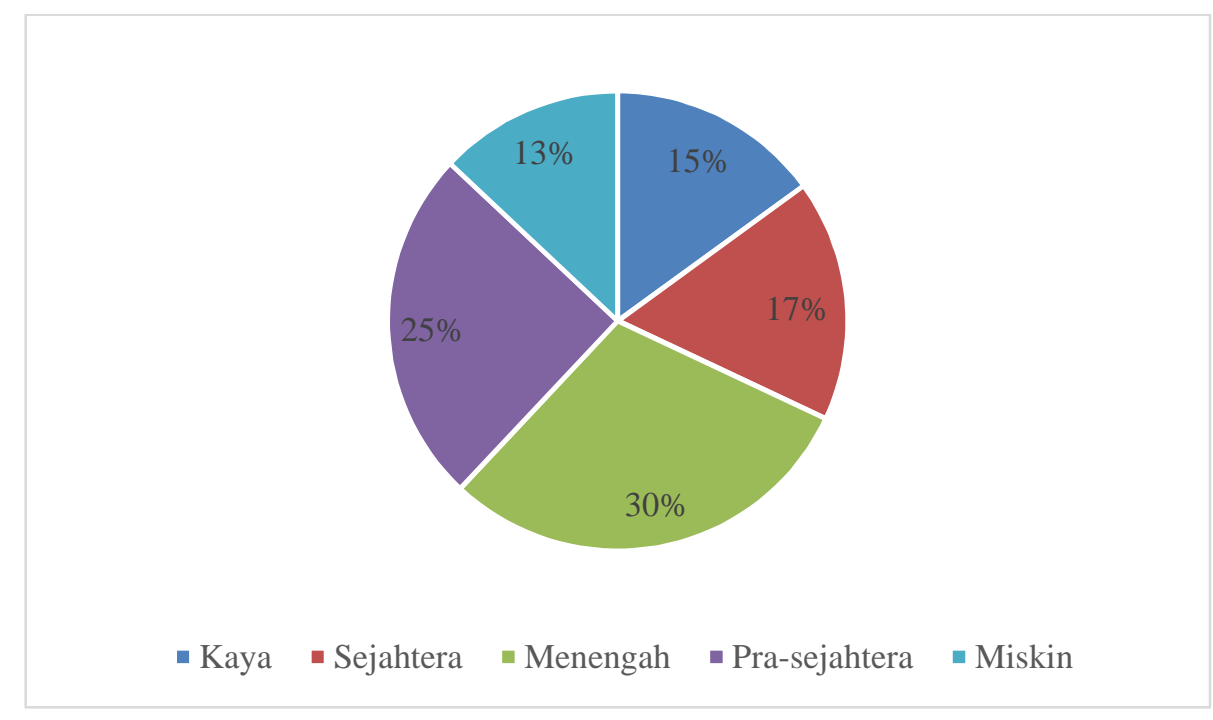

Gambar 2. Keadaan Perekonomian Penduduk

Sumber: Data Primer, 2019 
Sebagian wilayah daerah Desa Kubangwungu Kececamatan Ketanggungan Kabupaten Brebes dilihat dari mata pencaharian masyarakatnya mayoritas bekerja sebagai buruh tali tambang. Selebihnya berprofesi sebagai buruh kerja, petani, merantau ke kota-kota besar, berikut rinciannya:

Tabel 1. Mata Pencaharian Penduduk Desa Kubangwungu

\begin{tabular}{|c|c|c|c|c|}
\hline No & Pekerjaan & $\mathbf{L k}$ & Pr & Jumlah \\
\hline 1 & Belum/Tidak Bekerja & 1006. & 905. & 1911. \\
\hline 2 & Mengurus Rumah Tangga & & 1846. & 1846. \\
\hline 3 & Pelajar/Mahasiswa & 863. & 785. & 1648. \\
\hline 4 & Pensiunan & 3. & & 3. \\
\hline 5 & Pegawai Negeri Sipil & 11. & 2. & 13. \\
\hline 6 & Tentara Nasional Indonesia & - & - & - \\
\hline 7 & Kepolisian Ri & - & - & - \\
\hline 8 & Perdagangan & 263. & 47. & 310. \\
\hline 9 & Petani/Pekebun & 290. & 205. & 495. \\
\hline 10 & Peternak & & & \\
\hline 11 & Nelayan/Perikanan & 6. & - & 6. \\
\hline 12 & Industri & & 1. & 1. \\
\hline 13 & Konstruksi & 2. & - & 2. \\
\hline 14 & Transportasi & 10. & & 10. \\
\hline 15 & Karyawan Swasta & 155. & 67. & 222. \\
\hline 16 & Karyawan Bumn & - & - & - \\
\hline 17 & Karyawan Bumd & - & - & - \\
\hline 18 & Karyawan Honorer & 3. & 2. & 5. \\
\hline 19 & Buruh Harian Lepas & 267. & 223. & 490. \\
\hline 20 & Buruh Tani/Perkebunan & 208. & 139. & 347. \\
\hline 21 & Buruh Nelayan/Perikanan & 1. & - & 1 . \\
\hline 22 & Buruh Peternakan & - & 1. & 1. \\
\hline 23 & Pembantu Rumah Tangga & 1. & 41. & 42. \\
\hline 24 & Tukang Cukur & - & - & - \\
\hline 25 & Tukang Listrik & - & - & - \\
\hline 26 & Tukang Batu & 18. & & 18. \\
\hline
\end{tabular}




\begin{tabular}{llccc}
\hline No & \multicolumn{1}{c}{ Pekerjaan } & Lk & Pr & Jumlah \\
\hline 27 & Tukang Kayu & 10. & & 10. \\
28 & Tukang Sol Sepatu & - & - & - \\
29 & Tukang Las/Pandai Besi & 1. & & 1. \\
30 & Tukang Jahit & 9. & 2. & 11. \\
31 & Tukang Gigi & - & - & - \\
32 & Penata Rias & - & 2. & 2. \\
33 & Penata Busana & & & \\
34 & Penata Rambut & - & - & - \\
35 & Mekanik & 3. & - & 3. \\
36 & Seniman & - & - & - \\
37 & Tabib & - & - & - \\
38 & Paraji & - & 1. & 1. \\
\hline
\end{tabular}

Sumber: Data Primer, 2019

Adapun, potensi sumber daya manusia yang dapat dikembangkan untuk kegiatan pemberdayaan masyarakat berdasarkan dengan berbagai jenis mata pencaharian penduduk di Desa Kubangwungu adalah sebagai berikut:

Table 2. Potensi Sumberdaya Manusia

\begin{tabular}{clc}
\hline No. & \multicolumn{1}{c}{ Potensi Sumber Daya } & Jumlah \\
\hline 1. & Tenaga sarjana & 30 orang \\
2. & Tenaga bangunan terampil & 80 orang \\
3. & Pengrajin home industry & 185 orang \\
4. & Pengusaha & 27 orang \\
\hline
\end{tabular}

Sumber: Data Primer, 2019

Kegiatan kemasyarakatan di semua dusun tergolong aktif, baik dalam kegiatan masjid, pengajian, menyambut kemerdekaan, maulid Nabi, Isra' Mi'raj, dan kegiatan-kegiatan besar lainnya sehingga Sumber Daya Manusia (SDM) memiliki potensi untuk dikembangkan. Kegiatan ibu-ibu di Desa Kubangwungu yang dengan senang hati memeriahkan acara berbagai peringatan yang sederhana namun meriah, seperti halnya membuat bendera dan variasi hiasan untuk di jalan-jalan sepanjang desa, ada pula yang membuat tumpeng dan memasak bersama untuk Peringatan Hari Besar Islam. Kegiatan aktif pemudanya hampir sama dengan Ibu-Ibu namun mereka lebih membantu ke peralatan dan tenaga seperti membuat gapura, menyiapkan 
acara tujuh belasan dan menjadi panitia aktif di beberapa acara besar seperti kemerdekaan dan hari besar Islam. Kegiatan aktif anak-anak di desa Kubangwungu ini kebanyakan seperti anakanak di Desa lainnya yaitu naluri bermainnya masih ada, mereka kebanyakan bermain sepulang sekolah dan pada hari minggu, tetapi di Desa ini, anak-anak belum terlalu terpengaruh dengan gadget.

Kondisi tingkat kesehatan masyarakat sudah cukup baik, tidak ada masyarakat yang menderita penyakit parah dan aneh. Desa Kubangwungu memiliki puskesmas utama dan puskesmas pembantu. Serta, memiliki program posyandu di setiap RW serta memiliki program anserterpadu bagi ibu hamil, senam bagi lansia, dan penyuluhan bagi ibu hamil setiap satu bulan sekali. Kedaan lingkungan di Desa Kubangwungu kurang begitu bersih akibat banyaknya sampah rumah tangga dan limbah tali tambang yang dibuang secara sembarangan, serta belum tersedianya TPA. Selain itu, kurangnya kesadaran masyarakat dalam membuang sampah juga sangat rendah sehingga membuat keadaan lingkungan desa menjadi kurang bersih.

\section{Program Berkelanjutan Pemberdayaan Keluarga dalam Pilar Lingkungan}

\section{Membuat Kebun Bergizi di Kubangwungu}

a. Latar Belakang

Dengan kebun bergizi, kita dapat memanfaatkan lahan yang sempit atau teras depan rumah sebagai lahan untuk bercocoktanam dengan teknik vertikultur, sehingga bila kita membutuhkan rempah-rempah atau sayuran bisa langsung memetik tanpa harus pergi ke pasar untuk membelinya. Selain itu, secara tidak langsung kita juga dapat mengurangi limbah plastik.

b. Teknik

Menggunakan teknik vertikultur (bertingkat, berdiri, dan bergantung) dan penanaman secara langsung.

c. Bahan dan Media Tanam

Media tanam yang digunakan diantaranya yaitu botol air mineral, paralon, talang air, dan polibag. Sedangkan pengolahannya menggunakan bahan-bahan berikut: tanah, pupuk organik, dan abu.

d. Jenis Tanaman

Tanaman yang dibudidayakan yaitu cabai rawit, cabai lombok, sawi hijau, pare, kembang kol, tomat, jahe merah, bawang merah, terong ungu, mentimun putih, dan kangkung. 
2. Demo Pemanfaatan Limbah Rumah Tangga

a. Hasil Karya

1) Limbah media tanam dari plastik, botol plastik, dan kaleng bekas.

2) Perangkap nyamuk dari botol.

3) Lampion kardus, limbah yang digunakan kardus.

4) Lampion plastik, limbah plastik

5) Lampion sendok, limbah yang digunakan sendok plastik dan botol plastik.

6) Lampion benang, limbah yang digunakan benang jahit.

7) Perangkap tikus, limbah yang digunakan ember, kaleng, dan besi.

8) Pupuk bokashi, limbah yang digunakan kotoran ternak dan sekam padi.

\section{Pembuatan Biopori Di Lahan Kebun Bergizi}

a. Latar Belakang

Metoderesapan air yang ditunjukan untuk mengatasi genangan air dengan cara meningkatkan daya resapan air pada tanah.

b. Tempat

Dilahan tempat kebun bergizi Kubangwungu

c. Alat dan Bahan

1) Bor biopori

2) Palaron

3) Kawat

4) Semen

5) Pasir

6) Sampah organik

d. Cara Kerja

1) Buat lubang biopori dengan memutar bor biopori sampai dengan kedalaman tertentu

2) Pasang palaron dibagian atas lubang

3) Lubang di masukan sampah organik sampai penuh

4) Lubang biopori ditutupi dengan kawat dan dibagian pinggirnya ditutupi dengan semen

e. Fungsi

Manfaat secara ekologis dan lingkunga, yatu memperluas bidang penyerapan air, sebagai penanganan limbah organik dan meningkatkan kesehatan tanah 


\section{Bank Sampah}

a. Latar Belakang

Dalam dekade terakhir ini, permasalahan lingkungan hidup dan laju kerusakan serta pencemaran lingkungan semakin hari semakin meningkat. Persoalan lingkungan diantaranya adalah pengelolaan sampah karena menyangkut masyarakat luas an jika tiak ikelola dengan baik dapat menimbulkan dampak yang serius. Keseriusan merupakan kunci utama terdapat keberhasilan dalam permasalahan sampah, untuk itu peningkatan kesadaran, kepeulian, dan tanggung jawab masyarakat merupakan hal utama alam pengelolaan sampah, salah satunya dengan mendirikan bank sampah. Bank sampah adalah suatu tempat yang digunakan untuk mengumpulkan sampah yang sudah dipilah-pilah. Hasil dari pengumpulan sampah yang suah dipilah akan disetorkan ke tempat pembuatan kerajinan dari sampah atau ke tempat pengumpul sampah.

b. Jenis Sampah

1) Kertas
a) Kertas duplek
b) Kertas warna putih
c) Kardus
d) Koran
e) Kantong semen

2) Kaca
a) Orson
b) Kecap/saus
c) Beling-beling

3) Plastik
a) Plastik bening bersih, kotor dan sablon
b) Plastik kresek hitam, bening dan berwarna

4) Botol
a) Botol warna
b) Botol bening
c) Botol $600 \mathrm{ml}$

5) Gelas
a) Gelas bening
b) Gelas monte 
6) Besi ataupun seng

7) Sampah organik (daun-daunan) bisa dikelola menjadi pupuk kompos.

c. Mekanisme Bank Sampah

Adanya nasabah yang mengumpulkan sampah yang menyerahkan kepada teller di kantor bank sampah, kemudian sampah akan dihitung dan dicatat oleh teller di buku nasabah dan buku penerima. Terdapat dua kertas dengan warna yang berbeda, warna putih untuk naabah sebagai bukti menabung, seangkan yang warna merah sebagai kertas kendali. Sistem bagi hasil pada nasabah bisa bagi sekitar $85 \%$ bagi nasabah, dan $15 \%$ untuk khas bank sampah. Pengambilan hasil tabungan berasarkan kesepakatan nasabah dan pihak pengelola. Pemilihan sampah dilakukan oleh warga atau nasabah sebelum penukaran ke teller.

d. Mengadakan Penyuluhan

1) Tema

"Pelatihan dan Menajemen Bank Sampah bagi Masyarakat"

2) Tujuan

Untuk mengubah sampah menjadi komuditas sampah yang memiliki nilai ekonomis yang akhirnya bisa memberikan nilai tambah untuk masyarakat serta membantu mengurangi penumpukkan sampah.

3) Materi

Memilih, mengolah, mendaur ulang, dan menghasilkan produk.

\section{Pengolahan kembali limbah rumah tangga menjadi media tanam}

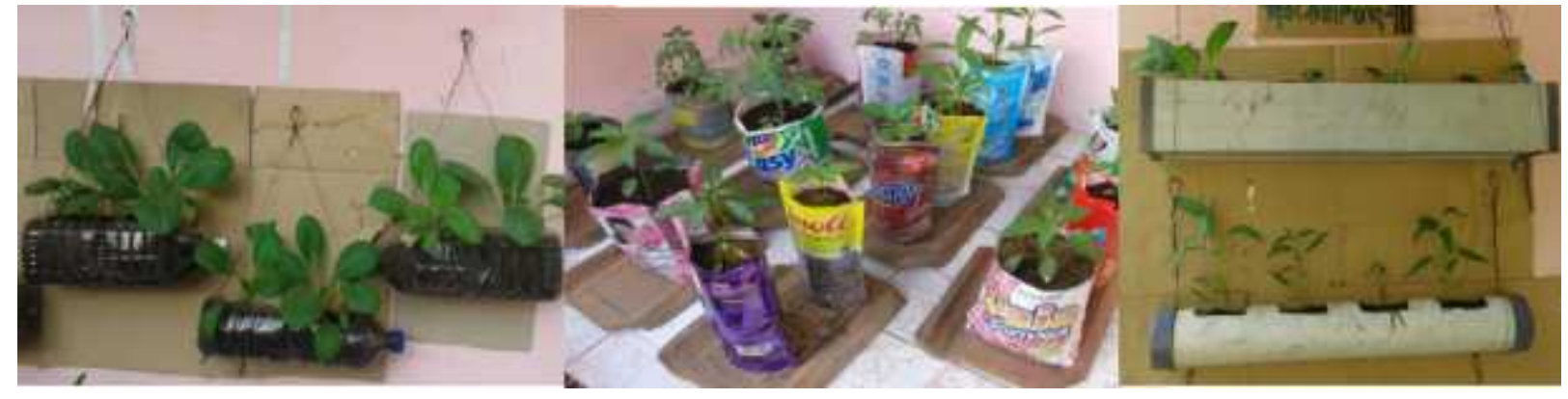

Gambar 1. Hasil Media Tanam dari Limbah Plastik, Botol Plastik dan Kaleng Bekas

(Dokumentasi pribadi)

a. Alat dan Bahan

1) Plastik detergen

2) Plastik pengharum baju

3) Plastik minyak 
4) Plastik makanan lainnya

5) Batol air mineral

6) Palaron

7) Talang air

8) Kaleng

b. Cara Pembuatan

1) Bahan yang dari botol dan paralon dilubangi dibagian atasnya, pada bagian bawah dilubangi sedikit untuk jalannya air keluar

2) Kemudian ikat dibagian ujung botol dan palaron dengan menggunakan kawat atau tali

3) Palaron yang sudah dilubangi di tanam tanaman dan bisa diletakkan ditembok atau disusun secara bertingkat

4) Bahan yang tebuat dari limbah plastik dan talang air dan kaleng bisa ditanam secara langsung

5) Bahan yang terbuat dari talang air bisa di susun secara bertingkat

\section{Pembuatan Alat Perangkap Nyamuk}

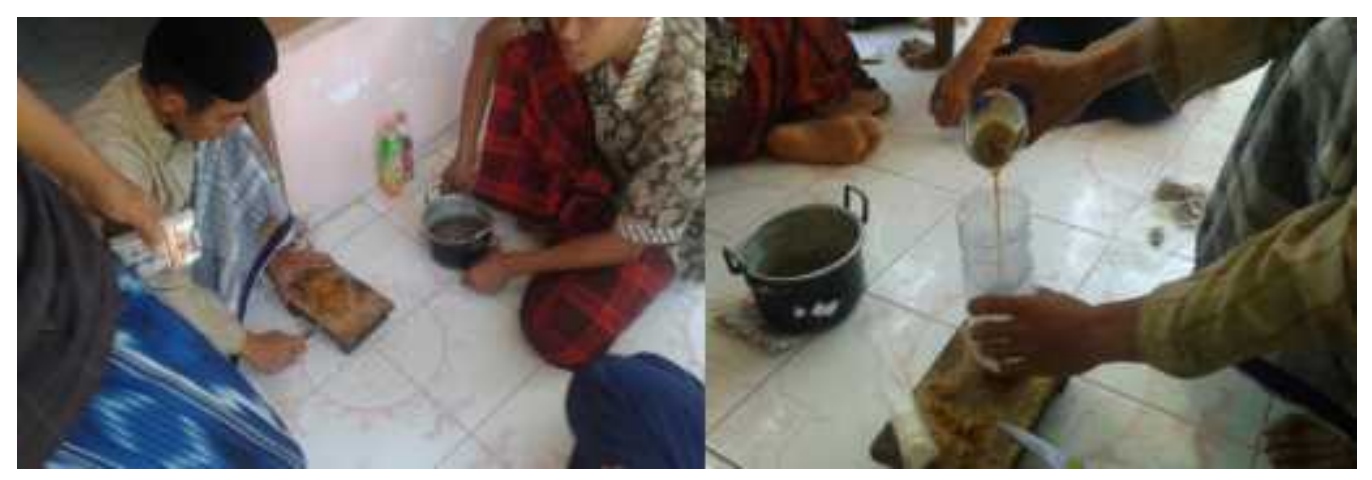

\section{Gambar 2. Proses Pembuatan Alat Perangkap Nyamuk dari Limbah Plastik}

(Dokumentasi pribadi)

a. Alat dan Bahan

1) Botol plastik ukuran 1,5 liter dipotong menjadi 2 bagian.

2) Air secukupnya. (kurang lebih $200 \mathrm{ml}$ )

3) Gula palem atau gula merah sekitar $5 \mathrm{gr}$

4) Ragi roti sekitar 1 gr 
b. Cara Pembuatan

1) Potong botol menjadi 2 bagian. Gunakan bagian bawah sebagai wadah, sedangkan bagian atas akan kita jadikan tutup nantinya.

2) Masukan gula palem dalam air hangat, sisihkan sampai dingin.

Campurkan ragi dalam larutan gula, tidak perlu diaduk. pada tahap ini karbondioksida akan terbentuk dan larutan ini akan menarik nyamuk.

3) Tuanglah larutan ini ke bagian bawah botol.

4) Taruh potongan bagian atas botol ke dalam botol dengan posisi terbalik (menyerupai corong).

5) Bungkus botol dengan plastik atau kertas berwarna hitam.

6) Letakan botol disudut ruangan dan periksalah setelah 2 minggu.

\section{Pembuatan Alat Perangkap Tikus}

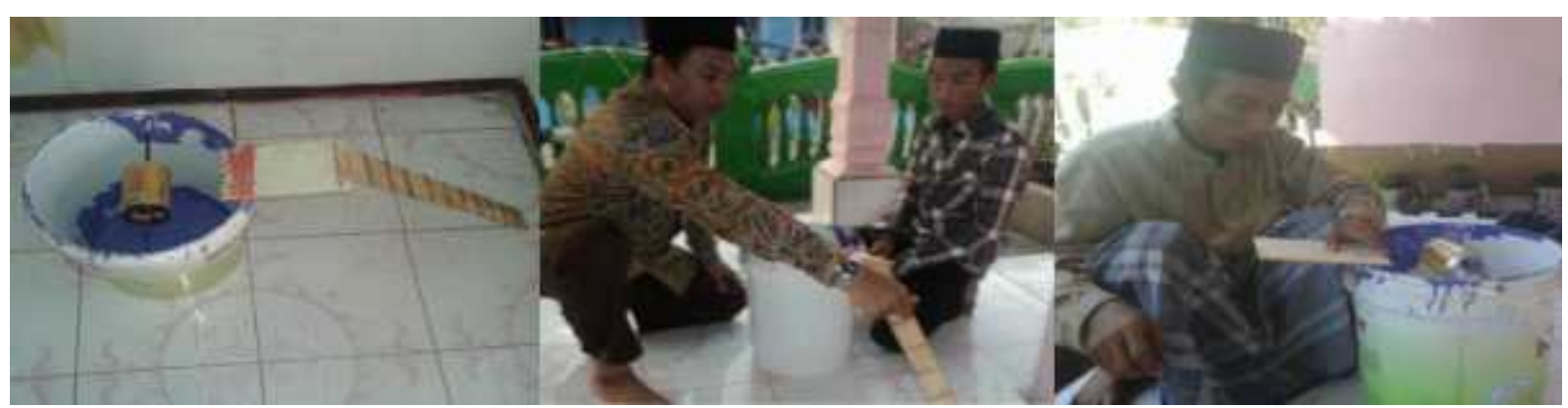

Gambar 3. Proses Pembuatan Alat Perangkap Tikus

(Dokumentasi pribadi)

a. Alat dan Bahan

1) Ember / kaleng berukuran cukup besar

2) Kaleng aluminium

3) Papan kayu / tripleks kecil.

4) Paku atau lem.

5) Batang besi silinder kecil yang berukuran lebih panjang sedikit dari diameter kaleng / ember besar

6) Umpan, cari yang dapat dioles seperti selai kacang ataupun ikan asin.

b. Cara Pembuatan

1) Buat roda perangkap dengan melubangi kaleng kecil tepat di bagian tengah pada kedua sisi datarnya (atas dan bawah)

2) Kemudian memasang besi silinder melewati kedua lubang tersebut. 
3) Setelah roda perangkap jadi, saatnya kita melubangi bagian atas kaleng/ ember besar dan memasang roda perangkap yang telah kita buat tadi ke tempat tersebut.

4) Oleskan selai kacang ke kaleng kecil sebagai umpan

5) Kaitkan papan kayu atau tripleks di atas lubang kaleng besar.

6) Tempatkan alat perangkap ini ke tempat strategis yang sering dilewati oleh tikus

7) Tuangkan air ke dalam ember besar agar tikus-tikus ini tidak dapat memanjat kaleng besar dengan mudah.

\section{Pembuatan Pupuk Bokashi}

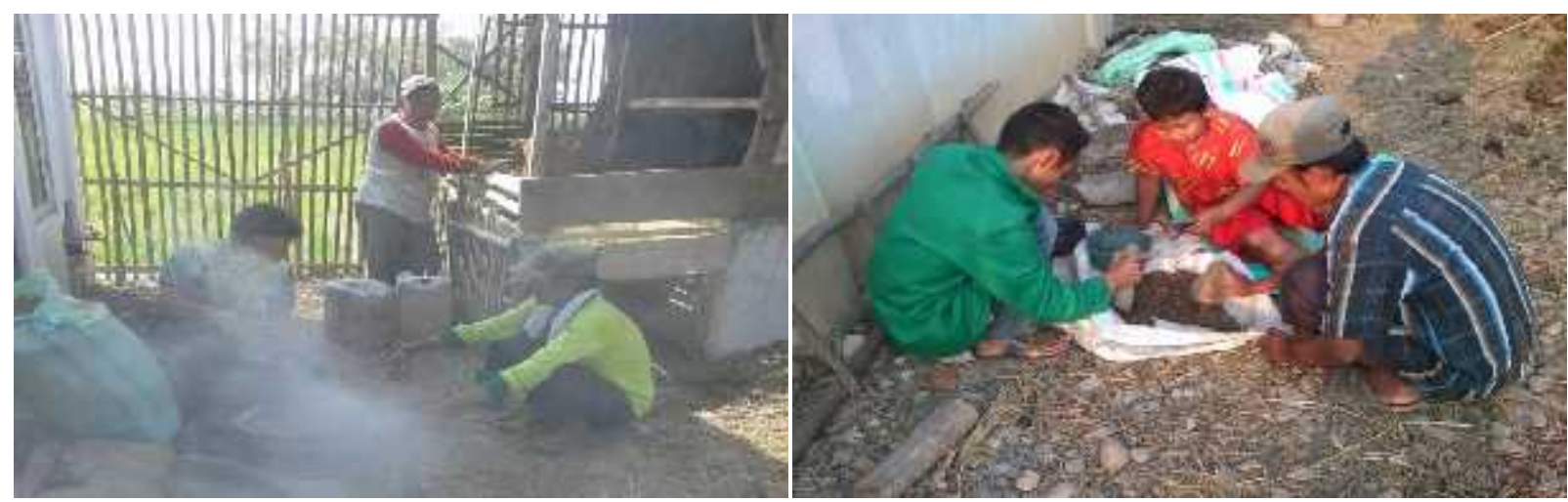

\section{Gambar 4. Proses Pembuatan Pupuk Bokashi}

(Dokumentasi pribadi)

a. Alat dan Bahan

1) Pupuk kandang sebanyak $15 \mathrm{~kg}$

2) Arang sekam sebanyak $10 \mathrm{~kg}$

3) Dedak $0.5 \mathrm{~kg}$

4) EM4 sebanyak $30 \mathrm{ml}$

5) Air secukupnya

b. Cara Pembuatan

1) Bahan pupuk kandang, arang sekam dan dedak dicampur sampai merata

2) Selanjutnya bahan tersebut disiram larutan EM-4 secara perlahan dan bertahap sehingga terbentuk adonan, kemudian adonan tersbut dibentuk gundukan selanjutnya ditutup dengan karung goni selama 3-4 hari.

3) Setelah 4 hari penutup dibuka. Pembuatan bokashi dikatakan berhasil apabila ditumbuhi jamur yang berwarna putih 


\section{Pembutan Lampion dari Limbah Kardus dan Plastik}

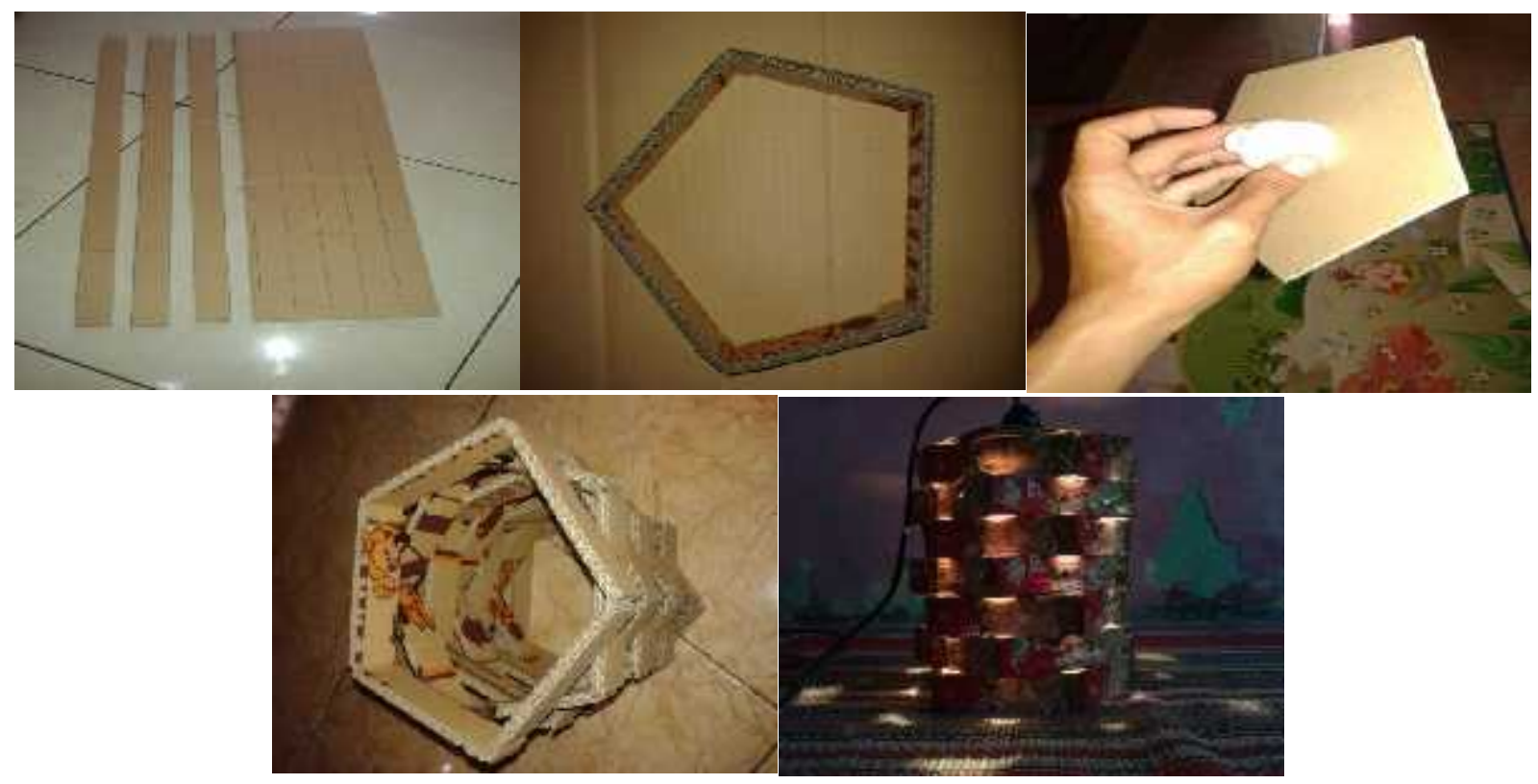

Gambar 5. Proses Pembuatan Lampion Berbahan Limbah

(Dokumentasi pribadi)

a. Alat dan Bahan

1) Kardus bekas

2) Penggaris

3) Pensil

4) Catter

5) Lem tembak/lem bakar

6) Kabel

7) Fitting

b. Cara Pembuatan

1) Siapkan kardus bekas, kemudian buat garis lurus 5 titik dengan ukuran yang sama dan diberi sekat untuk setiap titik

2) Langkah kedua potong kardus yang sudah diberi garis lurus dan potong setengah yang sudah diberi garis sekat

3) Kardus yang sudah dipotong kemudian dibentuk segi lima

4) Setelah diperoleh potongan segi lima kemudian dihubungkan satu dengan lainnya

5) Dibuat kap lampu bagian atas dengan bentuk segi lima sama sisi

6) Buat lubang ditengah-tenga bagian atas dari kap lampu yang telah kita buat sebelumnya sehingga ujung lampu dapat lampu menempel 


\section{Pembuatan Lampion dari Limbah Sendok Plastik}

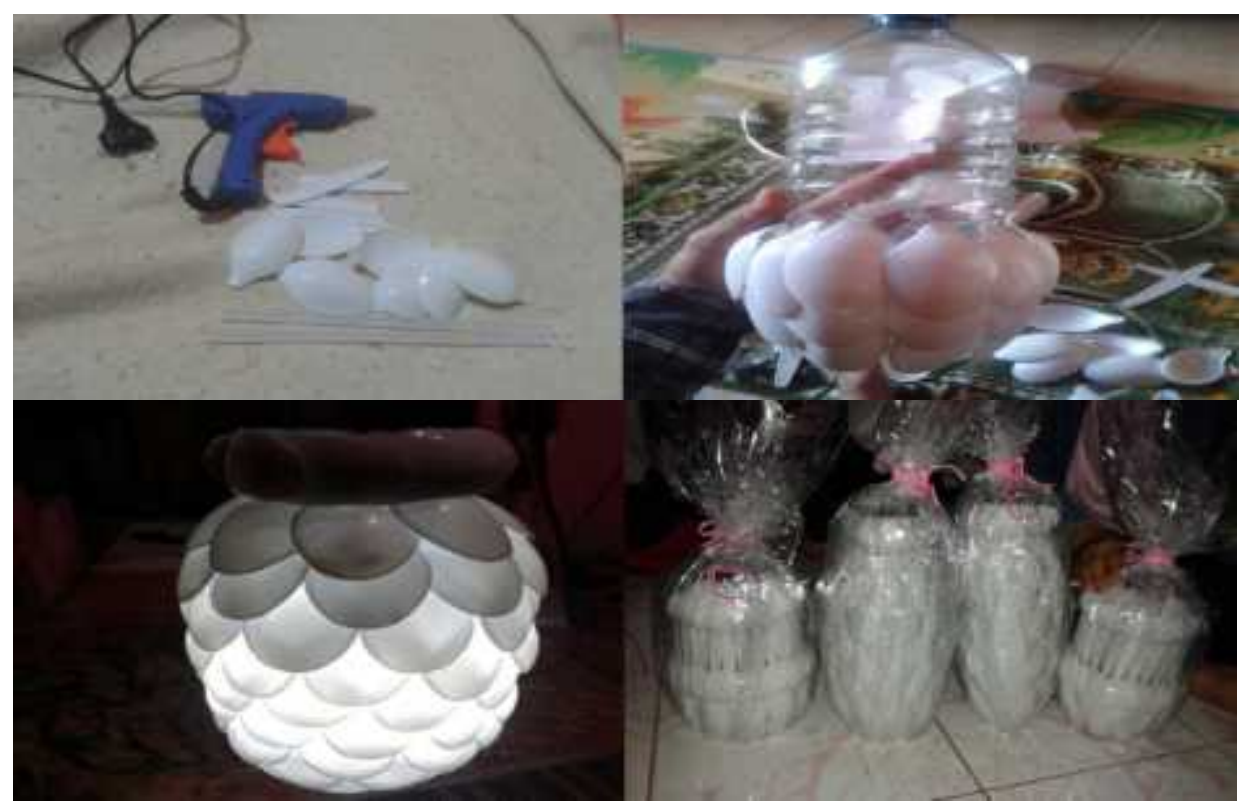

Gambar 6. Proses Pembuatan Lampion Berbahan Bekas

(Dokumentasi pribadi)

a. Alat dan Bahan

1) Sendok plastik

2) Botol, toples plastik

3) Penggaris

4) Pensil

5) Catter

6) Lem tembak/lem bakar

7) Kabel

8) Fitting

b. Cara Pembuatan

1) Bagian bawah botol dipotong secara merata kemudian bagian sendok dipotong antara bagian kepala dengan ganggang sendok

2) Rekatkan bagian kepala sendok dengan menggunakan lem bakar dan disusun secara merata dan rapi sampai bagian permukaan botol tertutup semua oleh sendok plastik

3) Lubangi bagian tutup botol plastik, kemudian buat rangkailah tempat, kabel dan kepiting secara benar

4) Lampion sendok plastik untuk diuji cobakan 


\section{Pembuatan Biopori}

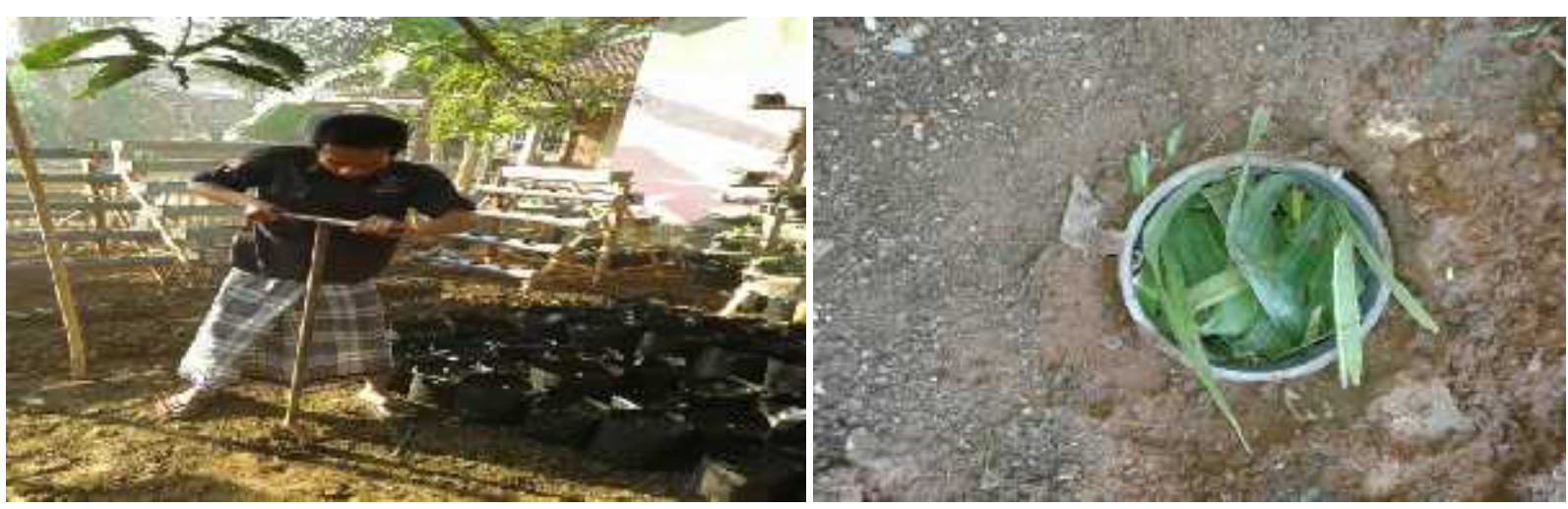

Gambar 7. Proses Pembuatan Biopori

(Dokumentasi pribadi)

a. Alat dan Bahan
1) Bor biopori
2) Palaron
3) Kawat
4) Semen
5) Pasir
6) Sampah organik

b. Cara Kerja

1) Buat lubang biopori dengan memutar bor biopori sampai dengan kedalaman tertentu

2) Pasang palaron dibagian atas lubang

3) Lubang di masukan sampah organik sampai penuh

4) Lubang biopori ditutupi dengan kawat dan dibagian pinggirnya ditutupi dengan semen

\section{UCAPAN TERIMAKASIH}

Kami mengucapkan banyak terimakasih kepada Tim Posdaya Kubangwungu yang diketuai oleh Ainun Mubarok yang sudah membantu dalam kegiatan survei dan Kepala Desa Windujaya, Roni Habilah yang telah berkontribusi mengizinkan sekaligus memberikan informasi yang dibutuhkan penulis dalam menyelesaikan penelitian ini. 


\section{DAFTAR PUSTAKA}

Desfandi, M. (2015). MEWUJUDKAN MASYARAKAT BERKARAKTER PEDULI LINGKUNGAN MELALUI PROGRAM ADIWIYATA. SOSIO DIDAKTIKA: Social Science Education Journal, 2(1), 31-37. https://doi.org/10.15408/sd.v2i1.1661

Naufal, A., \& Kusumastuti, Y. I. (2016). EVALUASI PROGRAM POS PEMBERDAYAAN KELUARGA (POSDAYA) (Studi Kasus Posdaya Bina Sejahtera di Kelurahan Pasirmulya, Kecamatan Bogor Barat, Kota Bogor, Jawa Barat). Jurnal Penyuluhan. https://doi.org/10.25015/penyuluhan.v6i2.11446

Nurul Inayah, \& Ribut Suprapto. (2017). Pendidikan Karakter melalui Pembentukan Bank Sampah Berbasis Pesantren di PP Ibnu Sina Genteng Banyuwangi. Engagement : Jurnal Pengabdian Kepada Masyarakat, 1(1), 14-27. https://doi.org/10.29062/engagement.v1i1.4 Ratnadewi. (2019). Pendampingan Komunitas Women Entrepreneur melalui Literasi Marketing Online di Jawa Barat. Engagement: Jurnal Pengabdian Kepada Masyarakat, 3(2). https://doi.org/10.29062/engagement.v3i2.30

Sunarsi, E. (2014). Konsep pengolahan limbah rumah tangga dalam upaya concept of household waste in environmental pollution. Ilmu Kesehatan Masyarakat. Retrieved from http://jikm.unsri.ac.id/index.php/jikm/article/view/268

Wahyudin, U. (2017). STRATEGI KOMUNIKASI LINGKUNGAN DALAM MEMBANGUN KEPEDULIAN MASYARAKAT TERHADAP LINGKUNGAN. Jurnal Common. https://doi.org/10.34010/common.v1i2.576

Zakiyyah, Z., \& Haqq, A. A. (2018). STRATEGI DAKWAH BIL HAL DALAM PROGRAM POSDAYA BERBASIS MASJID. ORASI: Jurnal Dakwah Dan Komunikasi. https://doi.org/10.24235/orasi.v9i1.2969

Zakiyyah, Zuhud, E., \& Sumardjo, S. (2016). Sikap Masyarakat dan Konservasi Kasus Stimulus Bakis Community's s Attitudes and Conservation A Case Stimulus of Vegetable Fern in Desa Gunung. Jurnal Pengelolaan Sumberdaya Alam Dan Lingkungan, 7(1), 71-76. https://doi.org/10.19081/jps1.6.1.71 